シンポジウム

「眼科検査のSkill up」

$E R G$ 検査と V E P 検査をより正確に行うための留意点

\author{
川 瀬 芳 克 \\ あいち小児保健医療総合センター

\section{Technical guidance in conducting more accurate electroretinography (ERG) tests and visual evoked potential (VEP) tests}

\author{
Yoshikatsu Kawase \\ Aichi Children's Health and Medical Center
}

要 約

網膜疾患の検查診断に使われる E R G 検查は眼科における電気生理検査の代表であるが、 I S C E Vの標準に従って杆体反応、杆体錐体混合反応、錐体反応、フリッカー反応を記録することで、 疾患の鑑別診断にさらに有用となる。

E R G 検查においては電極が角膜上に正しく置かれていることを常に確認することが正確な検査 結果を得る上に重要である。暗順応下で白色閃光により記録される E R Gはもっとも一般的に行わ れているが、この検查においても電極位置が不正であれば誤った波形が得られる可能性がある。

V E P 検查においては被験者の注意力や意識水準の確認が正確な検査結果を得るために不可欠で ある。パターンリバーサル刺激によるV E Pでは被検者が固視を維持し、パターンの反転を常に意 識できるように検者が誘導する必要がある。フラッシュVE Pを睡眠下で実施するときは、できる だけ浅い睡眠下で検査を実施することが望ましい。また、刺激への慣れによる反応の低下と疾患に よる反応の低下を鑑別するために患眼の反応を先に記録することや、V E P 波形であることを確認 するために背景脳波のみを加算したときの波形と視覚刺激を与えた場合の波形を比較するなどの工 夫が有効である。

別冊請求先（广474-0031）愛知県大府市森岡町尾坂田 $1-2$

あいち小児保健医療総合センター眼科 川瀬芳克

Tel. $0562-43-0500$

Key words : electrophysiological test, ERG, VEP

電気生理検查, ER G, V E P 


\begin{abstract}
An ERG test is regarded as the typical electrophysiological test used in screening for and diagnosing retinal disease in the field of ophthalmology. ERGs can serve as a more useful tool in making differential diagnoses of retinal disease if rod response, combined rod-cone response, cone response, and flicker response are recorded according to standards by the International Society for Clinical Electrophysiology of Vision (ISCEV).

In ERG tests, the electrode should be correctly set on the cornea, and its position should be constantly checked. Reliable results can be obtained through this rigorous process. Dark-adapted ERGs are recorded using a white flash. Even if this widespread examination method is adopted, the incorrect placement of electrodes may produce the wrong waveforms.

Checking the examinee's alertness and level of consciousness is indispensable in obtaining accurate results in VEP tests. To obtain VEPs using pattern reversal stimulation, the examiner should guide the examinee so that he/she can maintain fixation and constantly recognize the reversals of pattern. When flash VEPs are recorded during sleep, the examinee's level of sleep should be as shallow as possible. In order to differentiate decreased response due to repeated stimulations from decreased response due to illness, the responses of the suspected eye should be recorded in advance. Besides these techniques, comparisons between the waveform obtained by adding only background electroencephalograms and the waveform obtained after visual stimulation is recommended as an effective method of identifying VEP waveforms.
\end{abstract}

\section{I．ERG検査の有効性と検査上の留 意点}

1. ERG検査の標準化

International Society for Clinical Electrophysiological of Vision（以下ISCEVと略す）によ り ERG検査の標準化が提唱され、現在は1999年 版が最新版となっている1”。これは臨床で実施さ れる一般的なERG検查について標準規格を提唱 するもので、眼科臨床で日常的に行われている $\mathrm{ERG}$ 検査を制限するものではなく、さらに研究 等で実施される特殊なERG検査を含むものでは ない。検査機器の整備も必要でありすべての外 来ですぐに採用できるものではないが、ここで 示されている規格を周知しできる限りそれを満 たすように努力することでより正確なERG検査 が可能となる。

\section{2. 錐体機能と杆体機能の分離記録}

ISCEVはERG検査として杆体反応、杆体錐体 混合反応、錐体反応、 $30 \mathrm{~Hz}$ のフリッカーへの反 応を記録することを提唱している。このように
錐体系と杆体系の反応を分離して記録すること により ERG検査は疾患の鑑別診断により有用な 検査となる。

我々が使用しているポータブルERG LE-2000T M（トーメー製）は電極内に発光部が組み込ま れ、ISCEVに準拠した各種反応が簡易に記録で きることが特徴である（図 1, 図 2)。

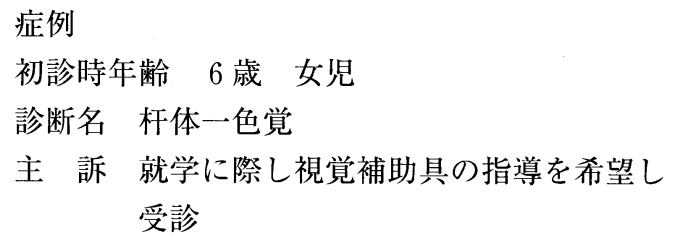

本症のERG検查では杆体反応が認められるの に対し、フリッカーに対する反応は認められな かった（図 3 、図 4 )。強い羞明、眼振、色覚

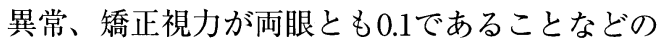
所見より本症を推定していたが、この結果より 本症と診断された。 


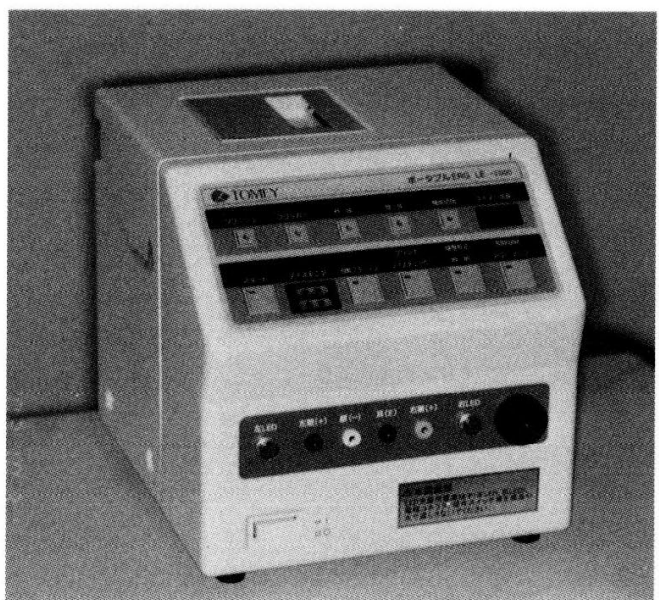

図 1 ポータブルERG LE-2000TM（トーメー製） の外観

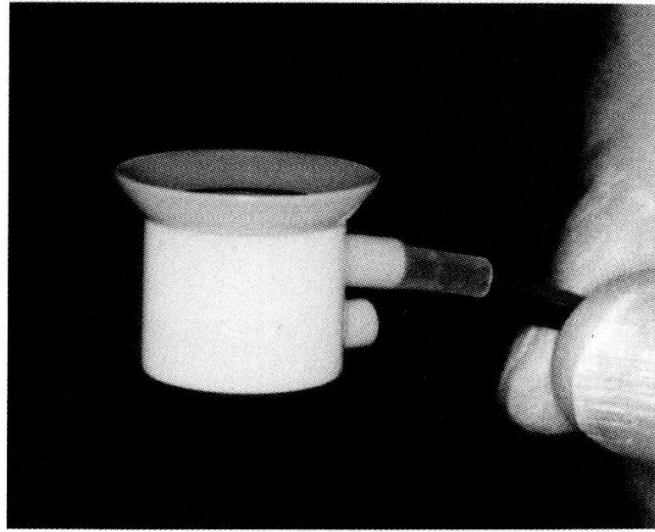

図 2 ポータブルERG LE-2000TM（トーメー製） の角膜電極

3. ERGによる先天性停止性夜盲症の鑑別

三宅によってその本体が解明された先天性停 止性夜盲症は、眼底に異常を認めず多くは視力 不良を主訴とするため、しばしば屈折異常性弱 視として管理されている ${ }^{213)}$ )。本症は白色閃光 による杆体錐体混合反応のERGでnegativeな波 形を示すため、特別な機器がない場合でも検査 が可能であり、両者は容易に鑑別される（図 5 )。

4. 角膜と角膜電極の位置関係による波形の変 化

角膜電極が正しく角膜上に置かれていること を常に確認していることが必要である。とくに 乳幼児や障害児（者）など検查者の指示が十分

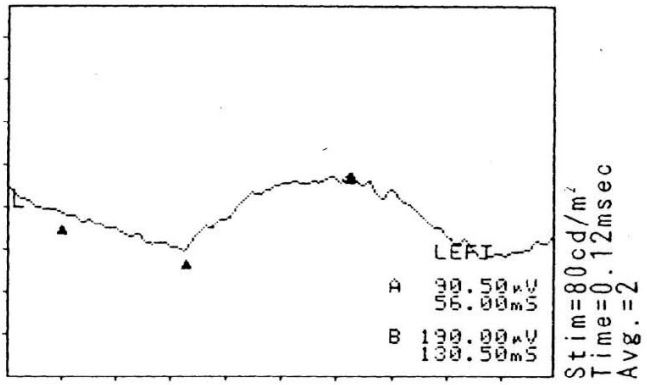

図 3 杆体一色覚児の杆体反応

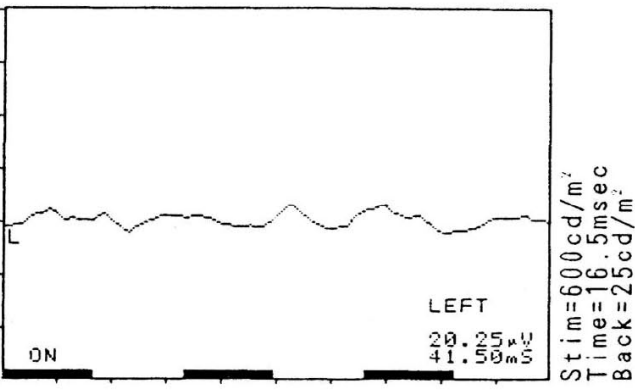

図 4 杆体一色覚児のフリッカーへの反応

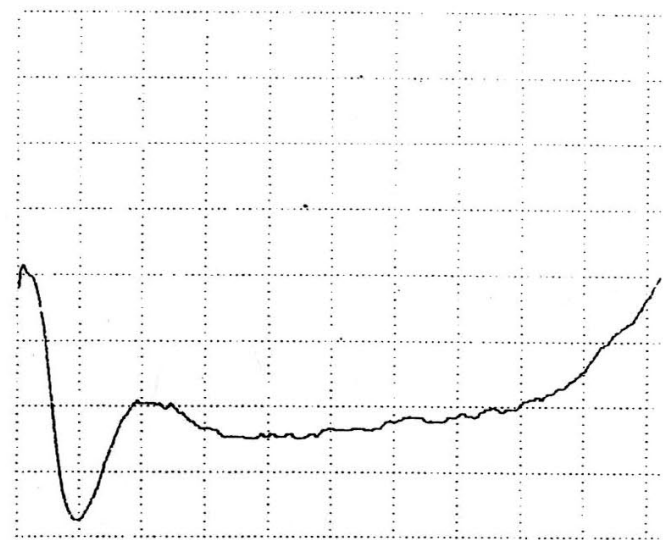

図 58 歳男児の先天性停止性夜盲症児より記録さ れた白色閃光によるERG波形

に伝わらないような場合には注意する必要であ る。たとえば片眼を検査する際には反対眼で固 視を誘導するなどの工夫などである。

角膜と電極の位置とERG波形の関係を模式的 に示すために、職員を被験者に白色閃光による ERGを記録した。眼を強く上転させ電極が角膜 から外れた状態でのERG波形はnon-recordable 


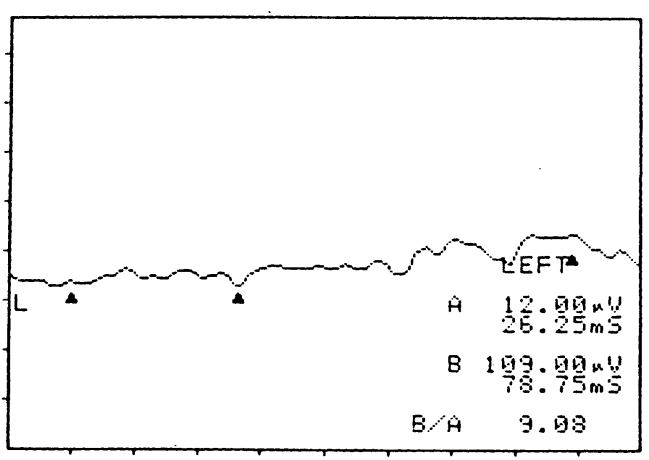

図 6 眼球を強く上転した状態で記録された正常者 の白色閃光によるERG波形

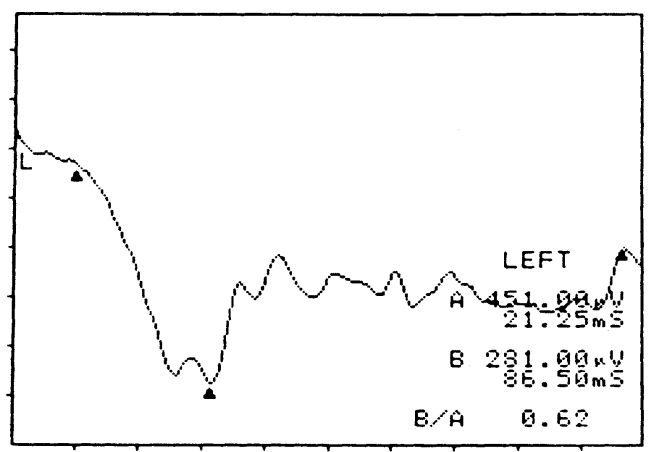

図 7 眼球を半ば上転した状態で記録された正常者 の白色閃光によるERG波形

様であった（図 6 ）。上転の程度を中等度とし 電極が角膜から半分程度外れた状態では negativeに似た波形を示した（図 7 )。これは基 線がやや右下がりとなっているためであるが誤 った情報となる波形である。電極位置が正しい 状態では正常なERG波形が記録されている（図 $8)$ 。

実際の記録例を示す（図 9 )。症例は 0 歳の 女児で、覚醒状態で記録されたERG波形であ る。ローバック型の角膜電極を使用して記録し た白色閃光によるERGで、発光時の角膜位置は 電極を通して筆者が肉眼的に確認していた。上 段の波形は角膜が外れていて確認できなかった 状態、中断はやや上転していて角膜が半ば認め られた状態、下段が角膜上に電極が置かれた状 態である。やや雑音が混入しているが正常波形 と認められた症例である。

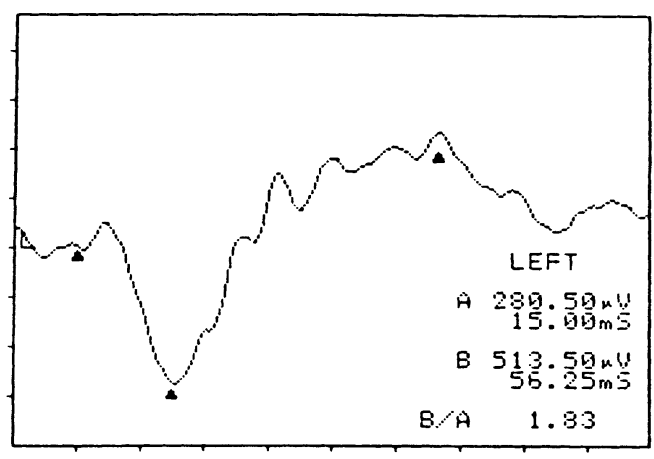

図 8 角膜上に電極を置いた正常位置で記録された 正常者の白色閃光によるERG波形

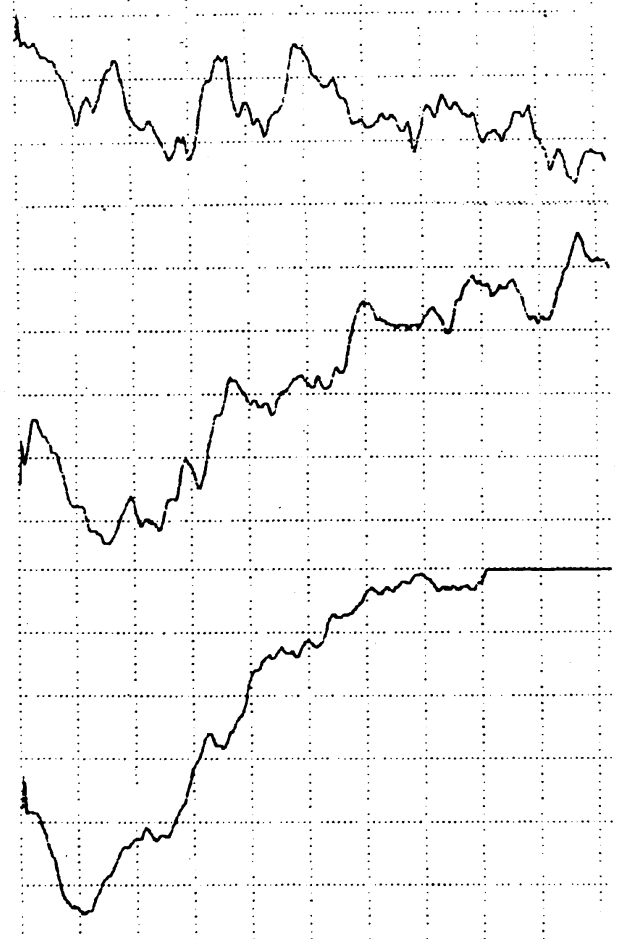

図 9 電極位置と白色閃光によるERG波形の記録例。 症例は 0 歳女児で、上段は眼球が上転し電極 が角膜から外れた状態、中段はやや上転し角 膜上から電極が半ば外れた状態、下段は角膜 上に電極が置かれた状態でそれぞれ記録され た波形。使用電極はローバック型であり、電 極位置は中央開口部を通して肉眼的に確認し た。 


\section{VEP検査を正確に実施するため の留意点}

筆者は神経眼科学会の標準化を参考にVEP検 查を行っているが、検査に際して留意している ことを以下にあげる5)。な提示した波形はすべ て関電極をマイナスにとったものである。

\section{a ．固視の監視}

パターンリバーサルによるVEPの検査に際し ては、被験者が刺激図形の固視点を注視し、刺 激図形が反転することを意識していることが大 切である。7 歳男児のVEP波形を示す（図10）。 上段のふたつの記録は固視点を注視していたと きの反応で再現性のあるP100の反応が認められ る。一方、下段のふたつの波形は注視が不十分 であった時のものでその反応が認められない。 このように正しい記録を得るためには固視点を 注視していることを十分監視している必要があ る。

Fix良

Fix正
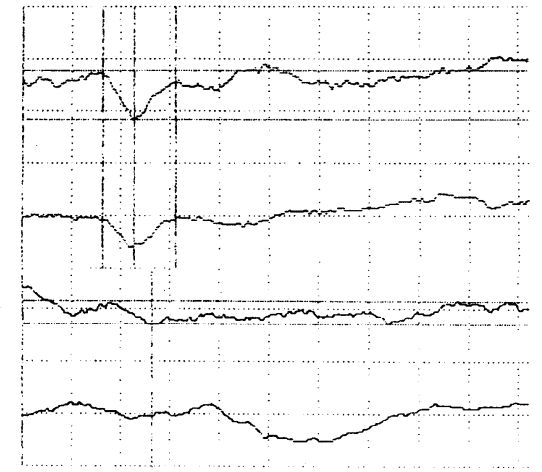

図107歳男児のパターンリバーサルVEPの波形。 上 2 段の波形は固視点を注視した状態、下 2 段の波形は注視不良の状態で記録されたもの である。

\section{b．意識水準の監視}

睡眠時のフラッシュVEP検査では被検者の意 識水準を脳波により監視し、できるだけ浅い睡 眠下においてVEPを記録することが必要であ る。知的障害を伴う 3 歳女览のフラッシュVEP の波形をしめす。(図11)。催眠剂を用いて睡眠 下で検査を行ったものであるが、上 3 段の波形 は中等度から深い睡眠時の反応波形であり、下 3 段は起こしながら浅い睡眠に誘導して記録し

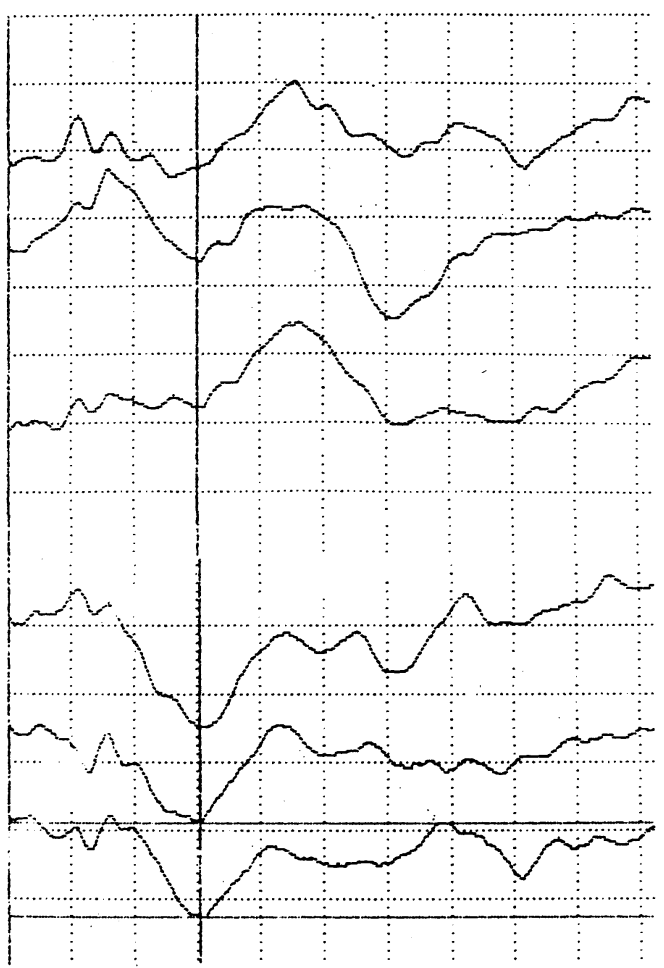

図11睡眠の深さによるフラッシュVEP波形の変化 の記録例。症例は 3 歳女児で、上 3 段は中等 度から深睡眠下、下 3 段は浅い睡眠下で得ら れたVEP波形である。

た波形である。いずれの波形も睡眠下で記録さ れたものであるが、浅い睡眠下では再現性ある 明暸な反応が認められている。

なお、スパイクや心電図等の混入や検査時の 発作などを感知するためにも脳波の監視は有効 である。

\section{c．対照波形の記録}

得られた波形がVEP反応であることを確認す るために背景脳波のみを加算した対照波形も記 録し比較することが有用である。対照波形は刺 激装置を含め検査機器は通常の検査時と同様に 動作させながら被検者に視覚刺激を与えないよ うにして記録している。フラッシュVEPではキ セノンの発光部を、光を通さない袋で完全に覆 うことで、発光はしながら被検者には光刺激を 与えないという状況を確保している。パターン VEPではパターン刺激を提示する T V モニタの 直前に十分大きい黒色のボードを置くことによ 
り T V モニタ上にはパターンを提示しながら、 被検者にはそれを提示しないようにした。なお、 ボードには固視点があり、被験者の注視を確保 している。

これにより視覚刺激が提示された時と提示さ れない時の波形が記録でき、両者を比較するこ とでより確かにVEP波形を評価することができ るようになる。とくに波形が不明暸である時に 有効である。

VEP波形と対照波形の例を示す。(図12）で ある。上 2 段が刺激を提示した時の反応波形で、 下 2 段が視覚刺激を提示しないで背景脳波のみ を加算して得られた波形である。両者を比較し て評価するが、視覚刺激を与えた場合にはVEP の成分が認められ、与えない場合にはその成分 が認められない平坦な波形が得られることで、 結果が確かなもので雑音等によるものでないこ とと、検査が正確に行われていることを確認し ている。

\section{d. 検査順序}

VEP検查を頻回繰り返すと反応波形の振幅が

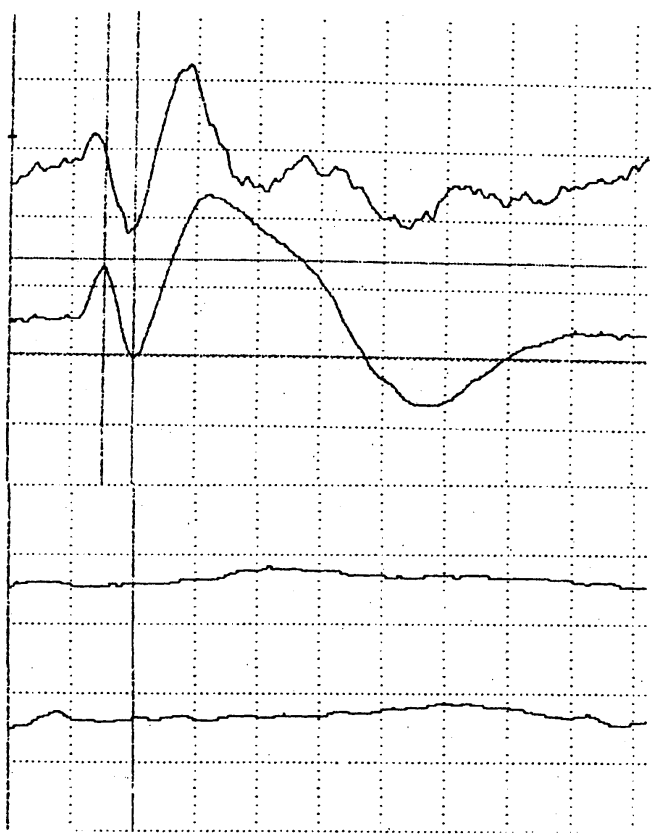

図12 VEP波形と対照波形の記録例。上 2 段は刺激 提示した状態、下 2 段は刺激提示なしの状態 で記録された波形。
低下することがある。これは刺激への慣れによ って起きると考えられるが、個人差も大きく定 量的に評価することは困難である。左右眼で反 応を比較する場合、反応を同時記録することが 理想的であるが、それができない場合は慣れに よる振幅の低下と疾病等による振幅の低下が区 別できるような順序で検查を実施する必要があ る。

左右眼で差があることが予想される場合、筆 者は両眼刺激、対照波形の記録、患眼刺激、健 眼刺激の順で検査を行っている。あとで実施し た健眼刺激時の波形の振幅より先に記録した患 眼刺激時の波形の振幅が明らかに小さい場合、

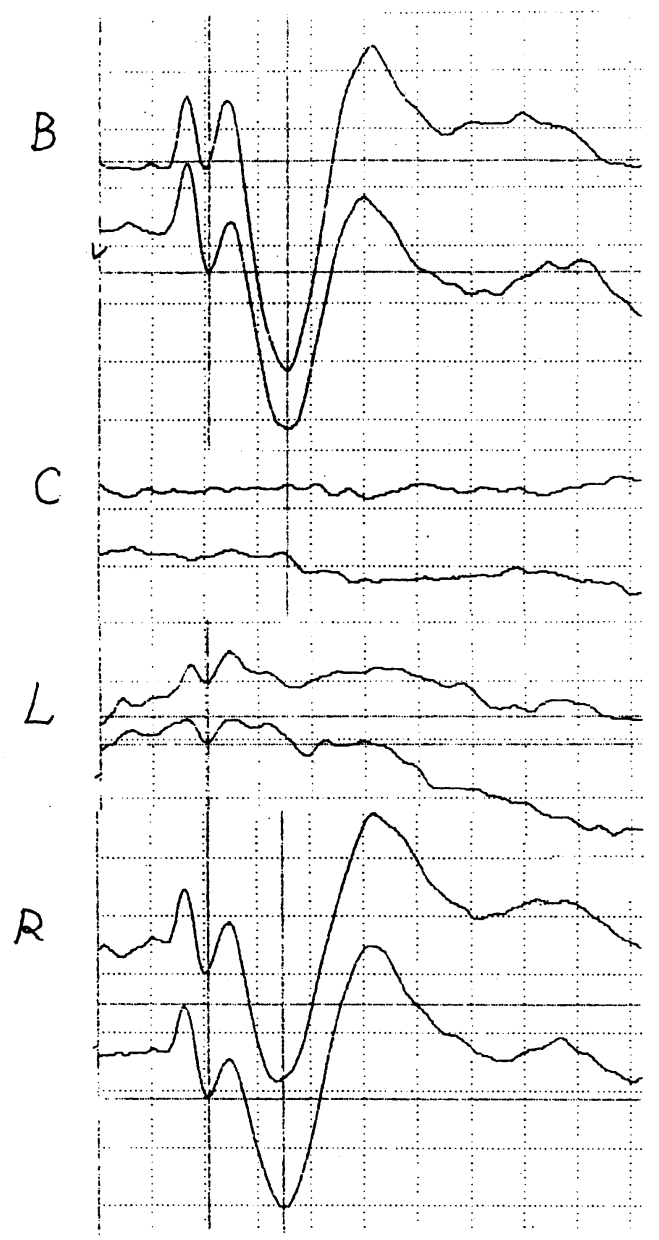

図13 左眼視神経萎縮（疑）の 2 歳男児のVEP波形。 上より両眼刺激、対照波形、左眼刺激、右眼 刺激の波形である。 $\mathrm{B}$ は両眼刺激、C は対照 波形、 L は左眼刺激、 $\mathrm{R}$ は右眼刺激を示す。 
患眼の反応が小さいと判定している。

左眼の視神経萎縮が疑われる 2 歳男児のVEP 波形を示す（図13）。各条件で 2 回ずつ検査を 行っているが、先に行った左眼の波形の振幅は あとで行った右眼のものより明らかに小さいこ とから、左眼の反応が小さいと判定した。

同様な例として左眼の先天性白内障が認めら れる 1 歳女児のVEP波形を示す（図14）。患眼 の反応が認められないことから左右眼差がある と判定した。なお、この例では睡眠の維持を確 保するため視覚刺激を与えない対照波形を最初 に行っている。

左右眼差が認められなかった例として、0 歳 女児の睡眠下でのフラッシュVEPの記録を示す （図15）。左眼内斜視が疑われ左右眼差を確認す るため検査を行った。異常が疑われた左眼の振 幅と、あとで検査を行った右眼の振幅に明らか な差が認められず、むしろ左眼の方がわずかに 振幅が大きい傾向が認められた。このことより 左右眼差は認められないと判定された。

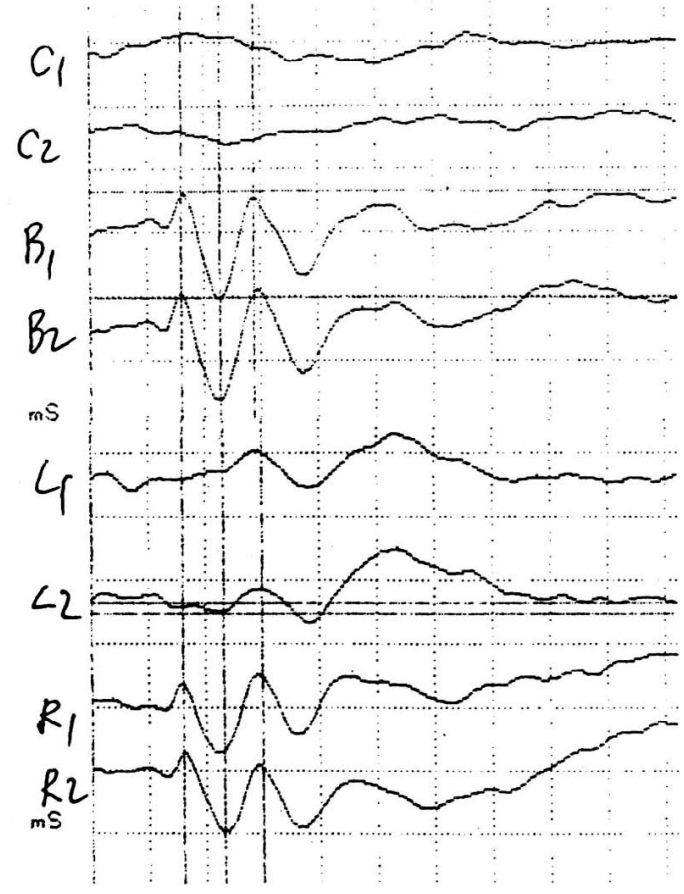

図14 左眼先天性白内障の 1 歳女览のVEP波形。上 より対照波形、両眼刺激、左眼刺激、右眼刺 激の波形である。C は対照波形、Bは両眼刺 激、L は左眼刺激、R は右眼刺激を示す。 e. 遮蔽の方法

片眼刺激に行うために非検査眼を遮閉するが、 これを確実に行うことが正確な検査のために不 可欠である。筆者は遮光性の黒い膜をアイパッ チより一回り小さく切り取り、これをアイパッ チで固定している（図16）。健眼からはごく微

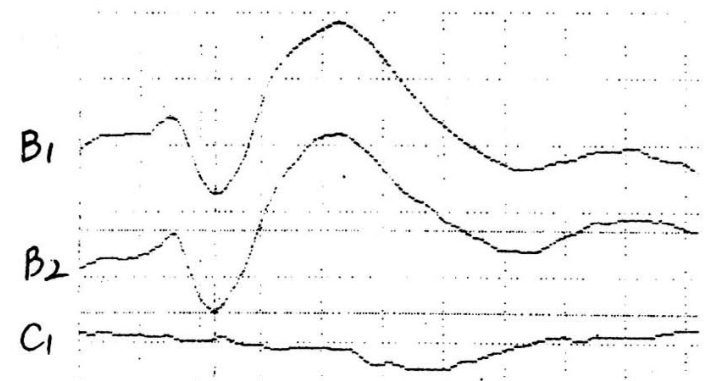

$C_{2}$

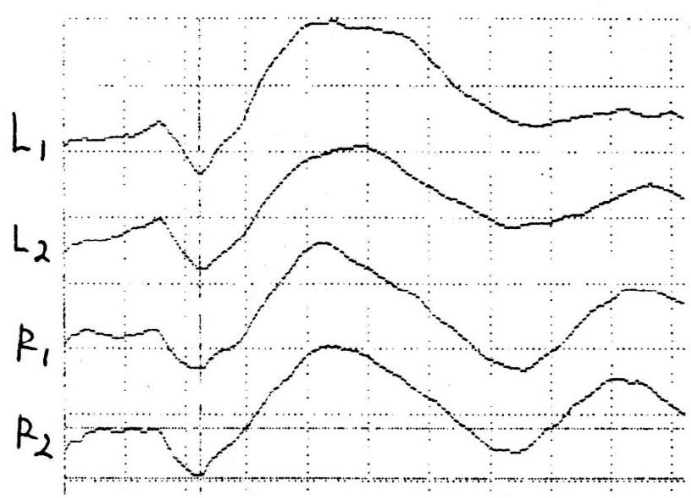

図15 左眼内斜視（疑）の1歳女览のVEP波形。上 より両眼刺激、対照波形、左眼刺激、右眼刺 激の波形である。Bは両眼刺激、C は対照波 形、Lは左眼刺激、 $\mathrm{R}$ は右眼刺激を示す。

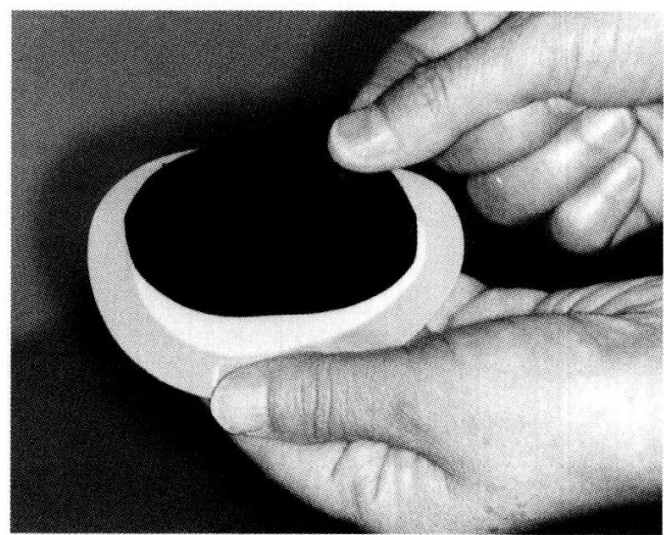

図16＼cjkstart遮閉用の膜とそれを固定するアイパッチ 
弱な光でも反応波形が得られるため、この遮蔽 は確実に行う必要がある。

\section{$\mathrm{f}$. 波形の評価}

波形の評価には再現性を重視している。少な くとも同一条件で 2 回の検査を行い、再現性の ある波形が得られた場合に反応としている。再 現性が不明瞭な場合には、時間間隔を置きなが らさらに $1 \sim 2$ 回の検査を追加している。

\section{$\mathrm{g}$. 雑音の除去}

正しい結果を得るためには雑音を除去するこ とは重要である。雑音を除去するためには電極 の抵抗を低くすること、正しくアースを取るこ と、ケーブルを束ねないことなどが必要である。

\section{まとめ}

ERGとVEP検査は眼科の代表的な電気生理検 查であり、網膜や視路の検查に不可欠なもので ある。他覚的検査であることから、乳幼児や障 害児（者）の検査としても重要である。これら
の検査においてより正しい信頼性の高い結果を 得るための留意点を述べた。

\section{参考文献}

1) Michael F.Marmor, Eberhart Zrenner: Standard for clinical electroretinography. Documenta Ophthalmologica 97: 143-156, 1999.

2 ) 三宅養三，他：新しい疾患概念の確立 先天 性停止性夜盲の完全型と不全型。日眼会誌 106 : 737-756, 2002.

3 ）川瀬芳克，内田尚子：先天性停止性夜盲症31 例の分析. 日本視能訓練士協会誌 $13: 108-111$, 1985.

4 ）三宅養三，柳田和夫，川瀬芳克，神田孝子： 狭義先天性停止性夜盲に関する研究（1）初 診時の主訴について。 日眼会誌 $88 ： 846-849$, 1984.

5 ）筒井純, 他：神経眼科領域における視覚誘発 脳波の応用に関する標準化. 眼臨76：13561368, 1982. 